\title{
Prognostic value of CD10, BCL6 and MUM1 in diffuse large B-cell lymphoma
}

Asmaa M. Ahmed ${ }^{a}$, Sally S. Abdel-Hakeem ${ }^{\text {b* }}$, Maged AF Amine ${ }^{\mathrm{c}}$, Etemad H. Yassin $^{\text {a }}$,Fatma A.M. Badary ${ }^{\mathrm{a}}$

${ }^{1}$ Pathology Department, Faculty of Medicine, Assiut University, Assiut, Egypt.

${ }^{2}$ Department of Oncologic Pathology, South Egypt Cancer Institute, Faculty of Medicine, Assiut University, Assiut, Egypt

${ }^{3}$ Medical Oncology Department, South Egypt Cancer Institute, Faculty of Medicine, Assiut University, Assiut, Egypt.

\section{Abstract}

Background: Diffuse large B-cell lymphoma (DLBCL) is considered the commonest subtype of non-Hodgkin lymphoma (NHL) in the world. It is a refractory disease with a high mortality rate due to frequent relapses. Several prognostic parameters are now widely studied for risk stratification and achieving a better outcome.

Objectives: In this study, we aim to assess the prognostic value of immunohistochemical expression of CD10, BCL6, and MUM1 independently as surrogate markers for cell of origin (COO) classification of DLBCL and their correlation with clinicopathological characters and survival.

Patients and methods: This is a retrospective study conducted on 63 cases of DLBCL, NOS. Full-faced sections were constructed and immunostained for CD10, BCL6, and MUM1.

Results: CD10 expression was associated with early-stage $(\mathrm{P}=0.003)$, normal serum LDH level ( $\mathrm{P}=0.022)$, absence of $\mathrm{B}$ symptoms $(\mathrm{P}=0.019)$, low international prognostic index (IPI) and age-adjusted-IPI $(\mathrm{P}=0.001)$ and also associated with longer progression free survival (PFS) $(\mathrm{P}=0.006)$. BCL6 expression was associated with centroblastic variant $(\mathrm{P}=0.005)$, good ECOG performance status $(\mathrm{P}=0.038)$ and low IPI $(\mathrm{P}=0.004)$ and also associated with better overall survival $(\mathrm{OS})(\mathrm{P}=0.028)$ and $\mathrm{PFS}$ $(\mathrm{P}=0.018)$. MUM1 expression was associated with advanced-stage $(\mathrm{P}=0.002)$ while no significant association was detected with other clinicopathological parameters or survival.

Conclusion CD10, BCL6, and MUM1 can be used independently as prognostic immunohistochemical markers for DLBCL that may denote the clinical behavior of the disease and further patients' outcomes.

Key words: CD10, BCL6, MUM1, DLBCL, survival.

\section{Introduction}

Diffuse large B-cell lymphoma (DLBCL) is considered the commonest subtype of non-Hodgkin lymphoma (NHL) in the world and accounts for $25 \%-35 \%$ of all adult NHLs (Teras et al., 2016). It is a refractory disease with a high mortality rate due to frequent relapses (Crump et al., 2017). The International Prognostic Index (IPI) is considered the most widely used parameter for predicting outcomes in patients with DLBCL, NOS. However, it is not sufficient for precise detection of treatment outcomes as being dependent on only clinical findings and not reflecting the biological features of

Copyright: () Ahmed et al. (2021) Immediate open access to its content on the principle that making research freely available to the public supports a greater global exchange of knowledge. Users have the right to Read, 
DLBCL cells (Shehata et al., 2019).CD10, BCL6, and MUM1 are the immunohistochemical markers that compromise the Hans' algorithm that is employed in dividing DLBCL according to the cell of origin (COO) into germinal center B-cell type (GCB) and activated $B$-cell type (ABC) with different prognostic outcomes.

CD10 is a membrane metalloproteinase that is found in a variety of lymphoid, stromal cells, and epithelial cells (Fabiani et al., 2005). BCL6 is a zincfinger transcriptional repressor that prevents premature B-cell activation and differentiation (Basso and Dalla-Favera, 2012). MUM1 is Multiple Myeloma Factor 1 or Interferon Regulatory Factor 4 (IRF4) transcriptional protein expressed in plasma cells and a small number of germinal center B cells (Dwivedi et al., 2015).

This study aims to assess the immunohistochemical expression of CD10, BCL6, and MUM1 in DLBCL, NOS specimens and correlate their expression with the clinicopathological features of DLBCL, NOS patients as well as the patients' survival.

\section{Patients and Methods}

The study was conducted retrospectively on sixty-three specimens of diffuse large B-cell lymphoma, NOS. The formalinfixed paraffin-embedded blocks were obtained from the archive of the surgical pathology lab of South Egypt Cancer Institute (SECI), Assiut University Hospital, Faculty of Medicine between 2011 and 2018. Only cases with available clinical data including follow-up data for at least one year after diagnosis and receiving CHOP therapy were included in this study. This study was approved by the ethical committee of South Egypt Cancer Institute. All available $\mathrm{H} \& \mathrm{E}$ and IHC stained slides were reviewed and reclassified based on the 2016 WHO classification criteria(Swerdlow SH, 2017).

Immunohistochemistry (IHC)

3 - $\mu$ m-thick sections were cut followed by deparaffinization and rehydration and blocking of endogenous peroxidase activity by $3 \% \mathrm{H} 2 \mathrm{O} 2$. Immersing the slides in citrate buffer ( $\mathrm{pH} \mathrm{6.0)} \mathrm{and} \mathrm{heating} \mathrm{at}$ $80^{\circ} \mathrm{C}$ in a microwave for 9 min was done for antigen retrieval. Then incubation with the primary antibodies (CD10,Rabbit polyclonal Antibody, Catalog number \# PA529354,dilution 1:100; BCL6, Monoclonal antibody, clone BL6.02 (PG-B6p)m, Catalog number \# MA5-11493,dilution 1:100; MUM1 Monoclonal Antibody (4G10), Catalog number\# MA515639, dilution 1:100; Thermo Fisher Scientific Corporation, Fremont, California, USA).Secondary staining kits were used according to the manufacturer's instructions (Thermoscientific Corporation, Fremont, California,USA).

IHC evaluation of CD10, BCL6, and MUM1

For each case, the fields with a higher percentage of stained tumor cells were used for the analysis. The positivity was identified as brown complete membranous staining for CD10 and nuclear staining for both BCL6 and MUM1. The intensity of the staining was not used to determine the positivity. The interpretation of each marker was done by a semiquantitative method through the examination of the whole immunostained slide. A cutoff point of $30 \%$ is used for all three markers as either positive (more than $30 \%$ positive tumor cells) or 
negative (less than $30 \%$ positive tumor cells) (Cho et al., 2018).

\section{Statistical analysis}

The statistical software package SPSS version 16 was used for all analyses. Descriptive statistical analysis was done for clinicopathological variables that include: Age, Gender, histological variant, serum LDH level, B symptoms, stage according to Ann Arbor criteria, ECOG performance status, BM involvement, IPI score, response to treatment, relapse/progression. Continuous variables were statistically described in terms of median (range), while categorical variables were presented as numbers and percentages. ChiSquare $(\chi 2)$ test was used for comparing categorical data. Exact test was used instead when the expected frequency is $<5$. Progression-free survival (PFS) and overall survival (OS) were calculated using Kaplan-Meier survival curves and the significance between the survival curves was evaluated by Log-rank test. PFS was considered as the period from initiating therapy to progression of the disease in patients with partial or complete remission; OS was the time from initiating therapy till the patient dies or till the time of the last follow-up visit. All $P$ values were two-tailed and considered statistically significant if $\leq 0.05$.

\section{Results}

\section{Clinicopathological characters}

The median age of the patients was fifty-two years old. Out of 63 cases, forty-two cases were presented with nodal involvement while the remaining cases were at extranodal sites. As regard tumor size; 59 cases were less than $10 \mathrm{~cm}$ while the remaining cases were more than $10 \mathrm{~cm}$. The histological variants included $71.6 \%$ centroblastic variant, $7.7 \%$ immunoblastic variant and $20.7 \%$ anaplastic variant. The clinical stages of the patients were grouped into earlystage (I-II) and advanced stage (IIIIV) with most of the cases $(70 \%)$ presented with advanced stage. BM involvement was reported in $32 \%$ of cases. Thirty-seven patients showed abnormal serum LDH level and twenty-two cases revealed the presence of B symptoms. The ECOG PS was grouped into good PS with a score 0-1 (54\%) and poor PS with a score $\geq 2$ in the remaining cases. As regarding IPI; 52.5\% of patients had low to intermediate risk while the rest of the patients had intermediate to high risk. Regarding Age-Adjusted IPI (AA-IPI); most patients $(74.7 \%)$ had intermediate to high risk. Follow-up data were available for 61 out of 63 patients. The median follow-up period of our study was 35 months, ranged from 4 to 128 months. The median OS was 32(ranged from 4 to 102). The median PFS was 35 (ranged from 4 to 128). At the end of the study, the total number of deaths was 12 cases and the number of the relapsed cases was 16.

Immunohistochemical results of CD10, BCL6, and MUM1 and their association with clinicopathological parameters

Seventeen out of 63 cases of DLBCL, NOS (26.9\%) were positive for CD10 while 46 cases (73.1\%) were negative. Regarding IHC results of BCL6, 37 cases $(58.7 \%)$ were positive and 26 cases $(41.3 \%)$ were negative. MUM1 was positive in 41 cases $(65 \%)$ and negative in 22 cases (35\%) (Figure 1).

Positive expression of CD10 was associated with female gender $(P=0.049)$, early stage $(\mathrm{I}, \quad$ II $)$ 
$(P=0.003)$, normal LDH level $(P=0.022)$, absence of $\mathrm{B}$ symptoms $(P=0.019)$, low IPI and AA-IPI $(P=0.001)$. About the IHC expression of BCL6, there was a significant association between positive BCL6 expression and centroblastic variant $(P=0.005)$, good ECOG PS $(P=0.038)$, and low
IPI $(P=0.004)$.Regarding the IHC expression of MUM1, the only significant association was found between positive MUM1 expression and advanced stage (III, IV) $(P=0.002)$ while no significant association was detected with other clinicopathological parameters. Table (1)

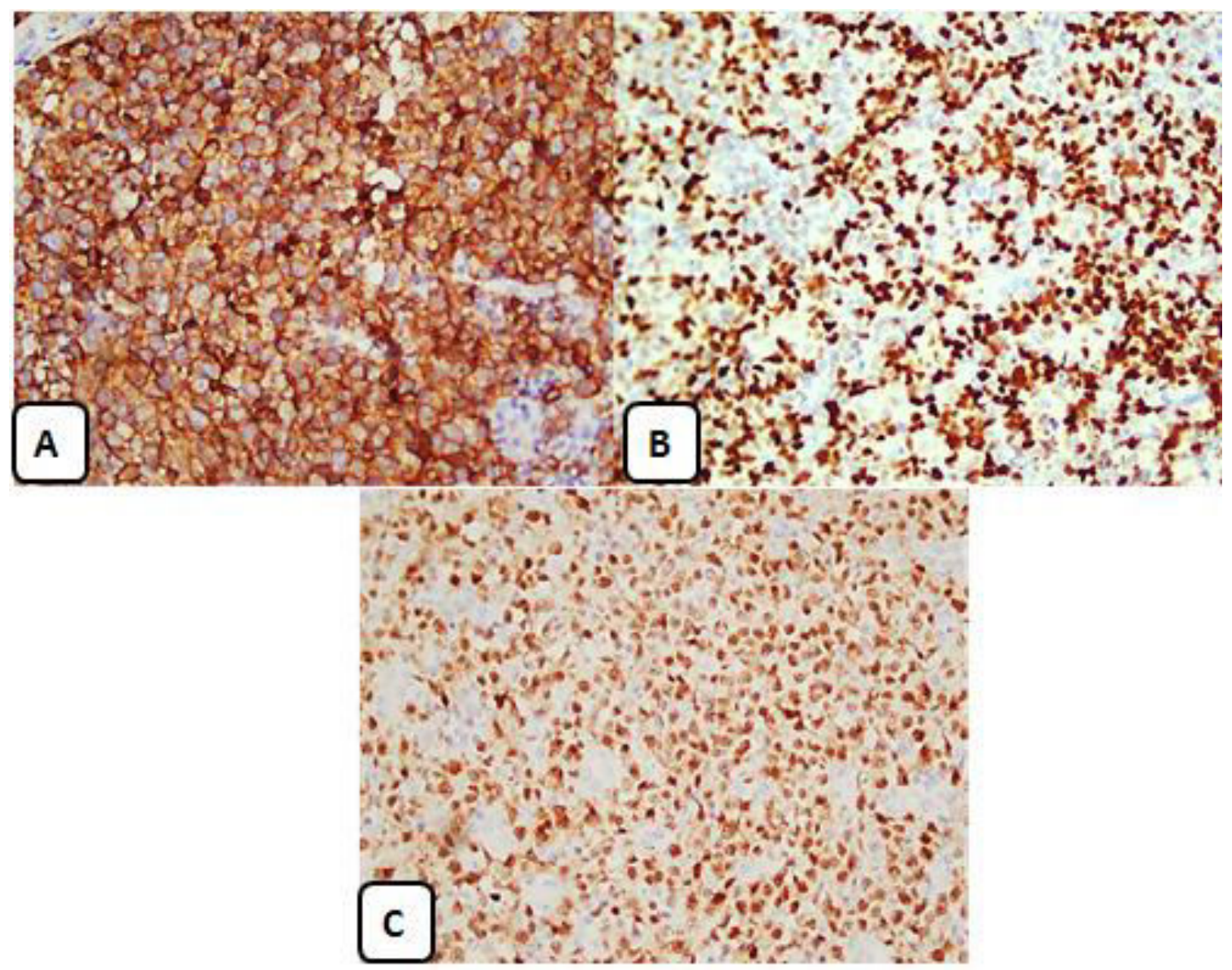

Figure (1): Positive immunohistochemicalexpression of (a) CD10, (b) BCL6, and (c) MUM1. 
Table (1): Association between IHC expression of CD10, BCL6 and MUM-1 and the clinicopathological parameters.

\begin{tabular}{|c|c|c|c|c|c|c|c|c|c|}
\hline \multirow{2}{*}{ Variables } & \multicolumn{2}{|c|}{ CD10 } & \multirow[b]{2}{*}{$P$-value } & \multicolumn{2}{|c|}{ BCL6 } & \multirow[b]{2}{*}{$P$-value } & \multicolumn{2}{|c|}{ MUM-1 } & \multirow[b]{2}{*}{$P$-value } \\
\hline & $\begin{array}{c}\text { Negative } \\
(n=46) \\
N(\%)\end{array}$ & $\begin{array}{c}\begin{array}{c}\text { Positive } \\
(\mathbf{n}=17) \\
\text { N }(\%)\end{array} \\
\end{array}$ & & $\begin{array}{c}\text { Negative } \\
(n=26) \\
N(\%)\end{array}$ & $\begin{array}{l}\begin{array}{l}\text { Positive } \\
(\mathbf{n}=37) \\
\mathbf{N}(\%)\end{array}\end{array}$ & & $\begin{array}{l}\begin{array}{c}\text { Negative } \\
(\mathbf{n}=22) \\
\mathbf{N}(\%)\end{array} \\
\end{array}$ & $\begin{array}{l}\begin{array}{l}\text { Positive } \\
(\mathrm{n}=41) \\
\mathbf{N}(\%)\end{array}\end{array}$ & \\
\hline $\begin{array}{l}\text { Age groups } \\
<60 \text { years } \\
\geq 60 \text { years }\end{array}$ & $\begin{array}{l}29(70.7) \\
17(77.3)\end{array}$ & $\begin{array}{ll}12 & (29.3) \\
5 & (22.7)\end{array}$ & 0.577 & $\begin{array}{l}14(34.1) \\
12(54.5)\end{array}$ & $\begin{array}{l}27(65.9) \\
10(45.5)\end{array}$ & 0.117 & $\begin{array}{ll}14 & (34.1) \\
8 & (36.4)\end{array}$ & $\begin{array}{l}27(65.9) \\
14(63.6)\end{array}$ & 0.860 \\
\hline $\begin{array}{l}\text { Sex } \\
\text { Female } \\
\text { Male }\end{array}$ & $\begin{array}{l}17(60.7) \\
29(82.9)\end{array}$ & $\begin{array}{l}11(39.3) \\
6(17.1)\end{array}$ & 0.049* & $\begin{array}{l}8(28.6) \\
18(51.4)\end{array}$ & $\begin{array}{l}20(71.4) \\
17(48.6)\end{array}$ & 0.067 & $\begin{array}{l}10(35.7) \\
12(34.3)\end{array}$ & $\begin{array}{l}18(64.3) \\
23(65.7)\end{array}$ & 0.906 \\
\hline $\begin{array}{l}\text { Tumor presentation } \\
\text { Nodal } \\
\text { Extranodal }\end{array}$ & $\begin{array}{l}32(76.2) \\
14(66.7)\end{array}$ & $\begin{array}{l}10(23.8) \\
7(33.3)\end{array}$ & 0.422 & $\begin{array}{l}20(47.6) \\
6(28.6)\end{array}$ & $\begin{array}{l}22(52.4) \\
15(71.4)\end{array}$ & 0.148 & $\begin{array}{l}15(35.7) \\
7(33.3)\end{array}$ & $\begin{array}{l}27(64.3) \\
14(66.7)\end{array}$ & 0.852 \\
\hline $\begin{array}{l}\text { Tumor size } \\
<10 \mathrm{~cm} \\
\geq 10 \mathrm{~cm}\end{array}$ & $\begin{array}{l}42(71.2) \\
4(100.0)\end{array}$ & $\begin{array}{l}17(28.8) \\
0(0.0)\end{array}$ & 0.567 & $\begin{array}{l}25(42.4) \\
1(25.0)\end{array}$ & $\begin{array}{l}34(57.6) \\
3(75.0)\end{array}$ & 0.637 & $\begin{array}{l}20(33.9) \\
2(50.0)\end{array}$ & $\begin{array}{l}39(66.1) \\
2(50.0)\end{array}$ & 0.606 \\
\hline $\begin{array}{l}\text { Histological variants } \\
\text { Centroblastic } \\
\text { Immunoblastic } \\
\text { Anaplastic }\end{array}$ & $\begin{array}{l}31(68.9) \\
5(100.0) \\
10(76.9)\end{array}$ & $\begin{array}{l}14(31.1) \\
0(0.0) \\
3(23.1)\end{array}$ & 0.406 & $\begin{array}{l}13(28.9) \\
4(80.0) \\
9(69.2)\end{array}$ & $\begin{array}{l}32(71.1) \\
1(20.0) \\
4(30.8)\end{array}$ & $0.005 *$ & $\begin{array}{l}18(40.0) \\
1(20.0) \\
3(23.1)\end{array}$ & $\begin{array}{l}27(60.0) \\
4(80.0) \\
10(76.9)\end{array}$ & 0.457 \\
\hline $\begin{array}{l}\text { Stage grouping } \\
\text { Early stage (I\&II) } \\
\text { Advanced stage(III\&IV) }\end{array}$ & $\begin{array}{l}9(47.4) \\
37(84.1)\end{array}$ & $\begin{array}{l}10(52.6) \\
7(15.9)\end{array}$ & 0.003* & $\begin{array}{l}8(42.1) \\
18(40.9)\end{array}$ & $\begin{array}{l}11(57.9) \\
26(59.1)\end{array}$ & 0.929 & $\begin{array}{l}12(63.2) \\
10(22.7)\end{array}$ & $\begin{array}{l}7(36.8) \\
34(77.3)\end{array}$ & $0.002 *$ \\
\hline $\begin{array}{l}\text { BM involvement } \\
\text { Free } \\
\text { Involved }\end{array}$ & $\begin{array}{l}29(67.4) \\
17(85.0)\end{array}$ & $\begin{array}{l}14(32.6) \\
3(15.0)\end{array}$ & 0.144 & $\begin{array}{l}17(39.5) \\
9(45.0)\end{array}$ & $\begin{array}{l}26(60.5) \\
11(55.0)\end{array}$ & 0.682 & $\begin{array}{l}13(30.2) \\
9(45.0)\end{array}$ & $\begin{array}{l}30(69.8) \\
11(55.0)\end{array}$ & 0.252 \\
\hline Serum LDH level & & & & & & & & & \\
\hline
\end{tabular}




\begin{tabular}{|c|c|c|c|c|c|c|c|c|c|}
\hline $\begin{array}{l}<500 \\
\geq 500\end{array}$ & $\begin{array}{l}15(57.7) \\
31(83.8)\end{array}$ & $\begin{array}{l}11(42.3) \\
6(16.2)\end{array}$ & $0.022 *$ & $\begin{array}{l}10(38.5) \\
16(43.2)\end{array}$ & $\begin{array}{l}16(61.5) \\
21(56.8)\end{array}$ & 0.704 & $\begin{array}{l}11(42.3) \\
11(29.7)\end{array}$ & $\begin{array}{l}15(57.7) \\
26(70.3)\end{array}$ & 0.303 \\
\hline $\begin{array}{l}\text { B symptoms } \\
\text { Present } \\
\text { Absent }\end{array}$ & $\begin{array}{l}20(90.9) \\
26(63.4)\end{array}$ & $\begin{array}{l}2(9.1) \\
15(36.6)\end{array}$ & 0.019* & $\begin{array}{l}12(54.5) \\
14(34.1)\end{array}$ & $\begin{array}{l}10(45.5) \\
27(65.9)\end{array}$ & 0.117 & $\begin{array}{l}8(36.4) \\
14(34.1)\end{array}$ & $\begin{array}{l}14(63.6) \\
27(65.9)\end{array}$ & 0.860 \\
\hline $\begin{array}{l}\text { ECOG PS } \\
\text { Good }(0-1) \\
\text { Poor }(2,3,4) \\
\end{array}$ & $\begin{array}{l}25(73.5) \\
21(72.4)\end{array}$ & $\begin{array}{l}9(26.5) \\
8(27.6)\end{array}$ & 0.921 & $\begin{array}{l}10(29.4) \\
16(55.2)\end{array}$ & $\begin{array}{l}24(70.6) \\
13(44.8)\end{array}$ & 0.038* & $\begin{array}{l}11(32.4) \\
11(37.9)\end{array}$ & $\begin{array}{l}23(67.6) \\
18(62.1)\end{array}$ & 0.643 \\
\hline $\begin{array}{l}\text { IPI } \\
\text { Low/ Intermediate (0-2) } \\
\text { Intermediate /High (3-4) }\end{array}$ & $\begin{array}{l}18(54.5) \\
28(93.3)\end{array}$ & $\begin{array}{l}15(45.5) \\
2(6.7)\end{array}$ & $0.001 *$ & $\begin{array}{l}8(24.2) \\
18(60.0)\end{array}$ & $\begin{array}{l}25(75.8) \\
12(40.0)\end{array}$ & $0.004 *$ & $\begin{array}{l}15(45.5) \\
7(23.3)\end{array}$ & $\begin{array}{l}18(54.5) \\
23(76.7)\end{array}$ & 0.066 \\
\hline $\begin{array}{l}\text { AA-IPI } \\
\text { Low/ Intermediate (0-1) } \\
\text { Intermediate /High(2-3) }\end{array}$ & $\begin{array}{l}6(37.5) \\
40(85.1)\end{array}$ & $\begin{array}{l}10(62.5) \\
7(14.9)\end{array}$ & $0.001 *$ & $\begin{array}{l}6(37.5) \\
20(42.6)\end{array}$ & $\begin{array}{l}10(62.5) \\
27(57.4)\end{array}$ & 0.723 & $\begin{array}{l}8(50.0) \\
14(29.8)\end{array}$ & $\begin{array}{l}8(50.0) \\
33(70.2)\end{array}$ & 0.143 \\
\hline $\begin{array}{l}\text { Response to therapy } \\
\text { Responder } \\
\text { Non-responder }\end{array}$ & $\begin{array}{l}36(80.0) \\
9(20.0)\end{array}$ & $\begin{array}{l}16(94.1) \\
1(5.9)\end{array}$ & 0.260 & $\begin{array}{l}20(80.0) \\
5(20.0)\end{array}$ & $\begin{array}{l}32(86.5) \\
5(13.5)\end{array}$ & 0.506 & $\begin{array}{l}18(81.8) \\
4(18.2)\end{array}$ & $\begin{array}{l}34(85.0) \\
6(15.0)\end{array}$ & 0.733 \\
\hline
\end{tabular}

Qualitative data are presented as n (\%). Chi-square analysis or Fisher Exact test were used for comparing qualitative variables. Significance defined by $p<0.05$. 


\section{Survival analysis}

Regarding the survival analysis according to each protein expression of Hans, no significant difference in OS was found according to CD10 expression yet CD10 expression was associated with better PFS (3-years OS, $\quad 88.2 \pm 7.8 \%$ VS $\quad 77.3 \pm 6.8 \%$ respectively, $P=0.311$ ) (3-years $\mathrm{PFS}$, $100 \%$ VS $71.7 \pm 7.3 \% \%$ respectively, $P=0.006)$.

BCL6 expression was associated with better OS and PFS (3-years OS, $88.1 \pm 5.7 \% \quad$ VS $\quad 69.4 \pm 9.8 \%$ respectively, $P=0.028$ ) (3-years $\mathrm{PFS}$, $85.1 \pm 6.2 \% \quad$ VS $\quad 70.6 \pm 10.1 \%$ respectively, $P=0.018$ ). . However, no significant difference in both OS and PFS between MUM1 positive and negative cases (3-years OS, $83.5 \pm 6.3 \%$ VS $\quad 76.0 \pm 9.5 \%$ respectively, $\mathrm{P}=0.269$ ) (3-years $\mathrm{PFS}$, $76.9 \pm 7.2 \% \quad$ VS $\quad 84.7 \pm 8.2 \%$ respectively, $\quad P=0.444)$.Figure (2\&3).
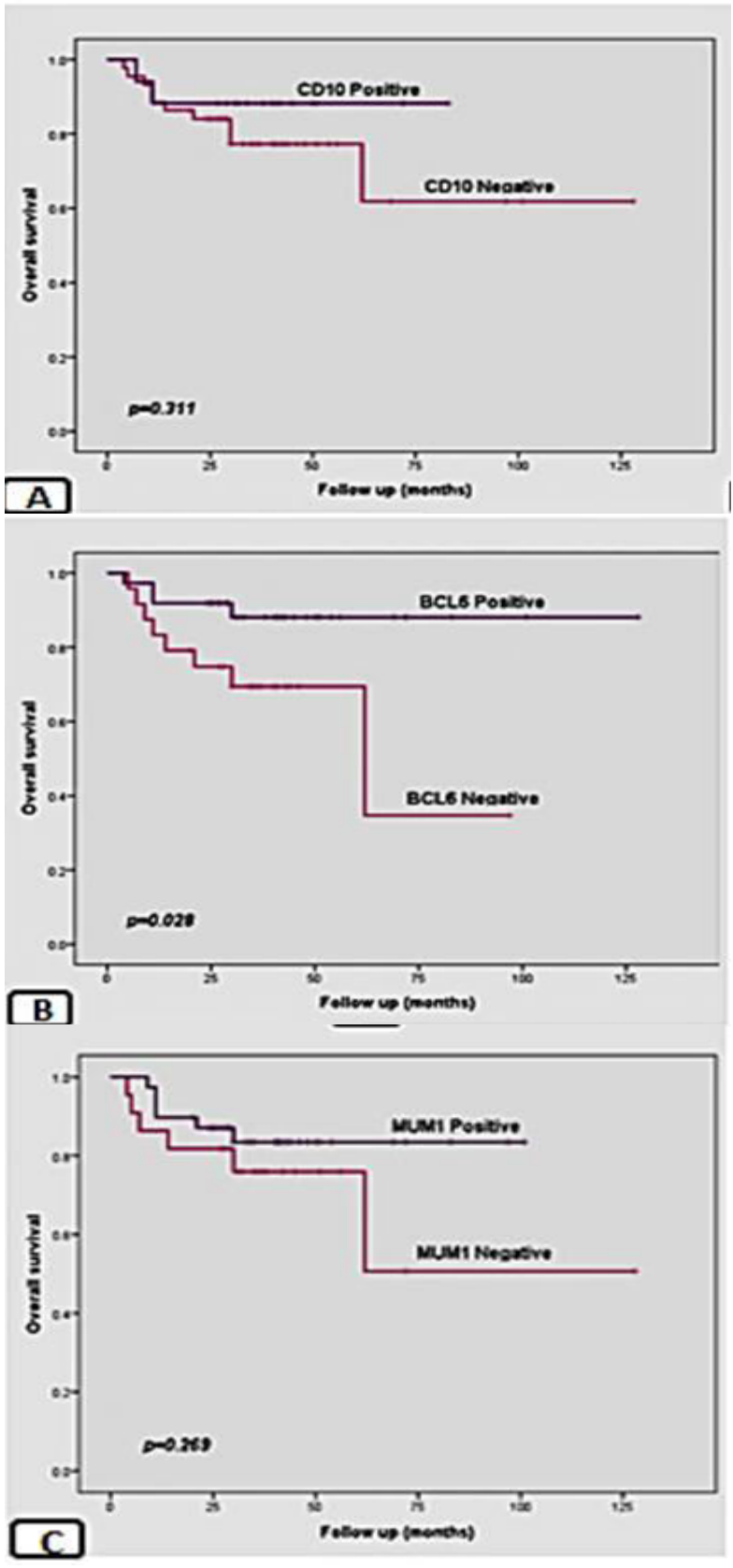

Figure (2):Kaplan-Meier curves for analysis of the expression of each protein of Han's algorithm (A: CD10, B: BCL6 and C: MUM1) and its relation to OS 

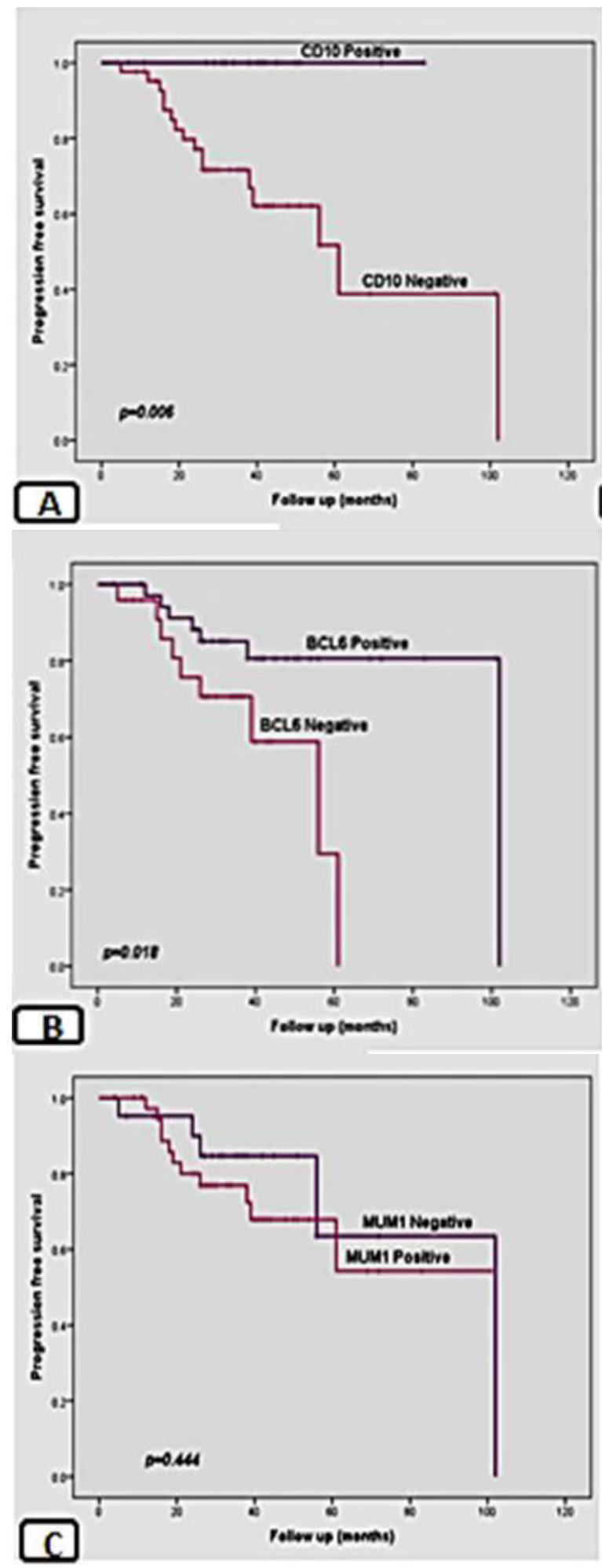

Figure (3):Kaplan-Meier curves for analysis of the expression of each protein of Han's algorithm (A:CD10, B: BCL6 and C: MUM1) and its relation to PFS

\section{Discussion}

Diffuse large B-cell lymphoma (DLBCL) is the most common subtype of NHL(Teras et al., 2016). Relapsed or refractory disease is considered the most common cause of death in DLBCL (Crump et al., 2017) and so, several prognostic parameters are now widely studied to achieve a better understanding of the biological and molecular features of DLBCL.

In this study, we aimed to assess the immunohistochemical expression of CD10, BCL6, and MUM1independently. All IHC stains were performed on full-faced sections of 63 samples of DLBCL, NOS obtained from the registry of SECI. CD10 was positive in $26.9 \%$ of cases and BCL6 was positive in $58.7 \%$ of cases. These results were correlated with the original study done by Hans et al(2004) in which CD10 and BCL6 positivity was recorded in 28 $\%$ and $56 \%$ of patients respectively. Higher expression of MUM-1 was detected in our study (65\%) which also found in other studies as that done by $\mathrm{Lu}$ et al where MUM-1 positivity detected in 65.9\%(2016) and Bajwa, et al (2017) where positive MUM-1 expression was found in $62.5 \%$ of cases. This high expression may hinder the prognostic performance of MUM-1 and because of this, a higher cut-off value of $80 \%$ for MUM-1 was applied in the Choi algorithm to achieve higher specificity for the ABC phenotype (Choi et al., 2009). In this study, we assessed the association between the expression of each marker and variable clinicopathological parameters including patients' survival. Our data revealed that positive $\mathrm{CD} 10$ expression was associated with early-stage, better PS, low IPI, normal LDH level, and absence of B 
symptoms. This is going in concordance with a study by Lu et al (2016). But, we found no significance between CD10 positive expression and achieving remission after therapy. This is in agreement with $\mathrm{Xu}$ et al(2001).

As regard survival, CD10 expression was associated with longer PFS, but no significant difference in OS rate between patients with CD10 positive and negative expression which agreed with Zhang et al (2012) and Peng et al (2017).

On the contrary, some previous studies conducted that CD10 expression may be associated with poor clinical outcomes (Uherova et al., 2001, Xu et al., 2001). This difference in these studies may be due to different number of cases where Uherova et al utilized only 28 cases of DLBCL, different methodology as both used flow cytometric immunophenotyping or different cut-off values where $\mathrm{Xu}$ et al used a threshold of $10 \%$ to estimate the positivity of CD10 and so, some authors presumed that the use of CD10 alone may be not reliable to predict survival (Asaad et al., 2016).

BCL6 positive expression was associated with good PS and low IPI which similar to results conducted by Coutinho et al(2013) while no correlation was found with other clinical parameters including response to therapy which is in agreement with studies done by Mahmoud et al (2011), Yan et al(2014) and Lu et al (2016). We also found that BCL6 expression was significantly associated with better OS and PFS which is in agreement with Bodoor et al (2012) and Devin et al (2019).

However, these results were in contrast to Jovanovic et al (2015) who had found that BCL6 expression was associated with poorer prognosis, and Dwivedi et al (2015) who couldn't found any difference in survival concerning to expression of BCL-6.

Although the presence of BCL6 rearrangement was more frequently observed in the non-GCB DLBCL (Jesse et al., 2010)and was included in the triple hit lymphoma (THL) along with MYC and BCL2 with further poorer clinical outcome; several studies reported the absence of any correlation between BCL6 rearrangement and BCL6 protein expression (Jesse et al., 2010, Shustik et al., 2010). Jovanovic et al also proposed that the prognostic value of BCL6 protein expression in DLBCL might be depending on the type of treatment used (Jovanovic et al., 2015).

As regards MUM1, the only positive correlation was detected between positive MUM1expression and advanced stage while no significant difference was detected in relation to the remaining clinicopathological parameters, which came in agreement with Ola et al (2015) and Lu et al (2016).MUM1 expression denotes the terminal $B$ cell differentiation toward plasma cells and the association of MUM1 expression and advanced stage explained by the fact that MUM1 expression is associated with constitutive activation of NF- $\kappa \mathrm{B}$ pathway with subsequent expression of other NF- $\kappa \mathrm{B}$ targeted genes which may be leading to chronically activated B cell receptor (BCR) signaling (Lenz et al., 2008). Hassan et al., 2014 reported that MUM1 expression was associated with poor clinical response (Hassan et al., 2014). This was in contrast to our study where there was no significant difference in response to therapy as regard MUM1 expression. Also, we 
found no significant difference in survival rates between patients with MUM1 positive and negative expression which agreed with Bodoor et al (2012) and Oh et al (2011), But against the study done by $\mathrm{Lu}$ et al (2016) who found that MUM1 expression was a significant predictor of worse OS and PFS.The study done by Van Imhoff et al found that a cutoff value of $30 \%$ for MUM-1 had no prognostic value while using a higher cutoff value of $70 \%$ might be required to achieve higher specificity and improve the prognostic performance of MUM-1 (van Imhoff et al., 2006). In conclusion, CD10, BCL6, and MUM-1 can be used independently as prognostic immunohistochemical markers for DLBCL that may denote the clinical behavior of the disease and further patients' outcomes.

\section{Acknowledgements}

This study was funded by the Research Grant Office, South Egypt Cancer Institute, Faculty of Medicine, Assiut University and approved by the ethical committee of the South Egypt Cancer Institute (Reference number IORG0006563, Approval number 411).

\section{Funding}

This study was funded by the Research Grant Office, South Egypt Cancer Institute, Faculty of Medicine, Assiut University.

\section{Conflict of interest}

The authors declared no conflicts of interest.

\section{Author contribution}

This work was carried out in collaboration between all authors. Author SSA conduct the study, performed the statistical analysis and wrote the first draft of the manuscript. Authors AMA, FAMB, MAFA, and EHY wrote the protocol and reviewed the manuscript. All authors read and approved the final manuscript.

References:

Asaad N, Abdel Wahed M, Abdou A, Serag El-Dien M Mohammed Kora M (2016). Prognostic impact of immunohistochemical stratification of diffuse large B-cell lymphoma into germinal and nongerminal subtypes. Menoufia Medical Journal, 29 (4): 961-970.

Bajwa AA, Khadim MT, Din HU, Ali SS, Jamil U Khan UaS (2017).

Immunohistochemical Expression of CD10, BCL6 and MUM1 in Differentiating Diffuse Large B Cell Lymphoma Subtypes. J Coll Physicians Surg Pak, 27 (10): 621-624.

Basso K Dalla-Favera R (2012). Roles of BCL6 in normal and transformed germinal center $B$ cells. Immunological Reviews, 247 (1): 172-183.

Bodoor K, Matalka I, Hayajneh R, Haddad Y Gharaibeh W (2012). Evaluation of BCL-6, CD10, CD138 and MUM-1 expression in diffuse large Bcell lymphoma patients: CD138 is a marker of poor prognosis. Asian Pac J Cancer Prev, 13 (7): 303746.

Cho MC, Chung Y, Jang S, Park CJ, Chi HS, Huh J, et al. (2018). Prognostic impact of germinal center B-cell-like and non-germinal center Bcell-like subtypes of bone marrow involvement in patients with diffuse large Bcell lymphoma treated with R-CHOP. Medicine (Baltimore), 97 (45): e13046. 
Choi WWL, Weisenburger DD, Greiner TC, Piris MA, Banham AH, Delabie J, et al. (2009). A New Immunostain Algorithm Classifies Diffuse Large B-Cell Lymphoma into Molecular Subtypes with High Accuracy. Clinical Cancer Research, 15 (17): 5494-5502.

Coutinho R, Clear AJ, Owen A, Wilson A, Matthews J, Lee $A$, et al. (2013). Poor concordance among nine immunohistochemistry classifiers of cell-of-origin for diffuse large B-cell lymphoma: implications for therapeutic strategies. Clin Cancer Res, 19 (24): 668695.

Crump M, Neelapu SS, Farooq U, Van Den Neste E, Kuruvilla J, Westin J, et al. (2017). Outcomes in refractory diffuse large B-cell lymphoma: results from the international SCHOLAR-1 study. Blood, 130 (16): 18001808.

Devin J, Kassambara A, Bruyer A, Moreaux J Bret C (2019). Phenotypic Characterization of Diffuse Large B-Cell Lymphoma Cells and Prognostic Impact. Journal of Clinical Medicine, 8: 10741092.

Dwivedi A, Mehta A Solanki P (2015). Evaluation of immunohistochemical subtypes in diffuse large Bcell lymphoma and its impact on survival. Indian Journal of Pathology and Microbiology, 58 (4): 453-458.

Fabiani B, Delmer A, Lepage E, Guettier C, Petrella T, Brière J, et al. 2005. CD10 expression in diffuse large B- cell lymphomas does not influence survival,Ed.

Hans CP, Weisenburger DD, Greiner TC, Gascoyne RD, Delabie J, Ott G, et al. (2004). Confirmation of the molecular classification of diffuse large B-cell lymphoma by immunohistochemistry using a tissue microarray. Blood, 103 (1): 275-82.

Hassan U, Ishtiaq S Hussain M (2014).

Immunohistochemical expression of CD-10, BCL-6 and MUM-1 antibodies and immediate clinical response in patients of diffuse large Bcell lymphomas after six cycles of chemotherapy. J Coll Physicians Surg Pak, 24 (10): 722-7.

Jesse S, Guangming H, Pedro F, Nathalie AJ, Susana Ben N, Joseph MC, et al. (2010). Correlations between BCL6 rearrangement and outcome in patients with diffuse large B-cell lymphoma treated with CHOP or R-CHOP. Haematologica, 95 (1): 96101.

Jovanovic MP, Mihaljevic B, Jakovic L, Martinovic VC, Fekete MD, Andjelic B, et al. (2015). BCL2 positive and BCL6 negative diffuse large $\mathrm{B}$ cell lymphoma patients benefit from RCHOP therapy irrespective of germinal and non germinal center B cell like subtypes. J BUON, 20 (3): 820-8.

Lenz G, Wright G, Dave SS, Xiao W, Powell J, Zhao H, et al. (2008). Stromal gene signatures in large-B-cell lymphomas. N Engl J Med, 359 (22): 2313-23. 
Lu T-X, Miao Y, Wu J-Z, Gong Q$X$, Liang J-H, Wang $Z$, et al. (2016). The distinct clinical features and prognosis of the $\mathrm{CD}^{+} 0^{+} \mathrm{MUM}^{+}$and $\mathrm{CD}^{-} \mathrm{Bc}^{-} 6^{-} \mathrm{MUM}^{-}$diffuse large B-cell lymphoma. Scientific reports, 6: 2046520465.

Mahmoud HM El-Sakhawy YN (2011). Significance of Bcl-2 and Bcl-6 immunostaining in B-Non Hodgkin's lymphoma. Hematology reports, 3 (3): e26-e26.

Oh S, Koo DH, Suh C, Kim S, Park BH, Kang J Huh J (2011). Prognostic value of immunohistochemical

biomarkers at different cutoff values in patients with diffuse large B-cell lymphoma treated with CHOP chemotherapy. Journal of Korean medical science, 26 (12): 1556-1562.

Ola K, Amany H, Yasser AS, Asmaa S Mohammad A (2015). Clinicopathologic Profile and Outcome of Extranodal Diffuse Large BCell NHL: Egyptian National Cancer Institute Experience. Forum of Clinical Oncology, 6 (3): 8-12.

Peng F, Guo L, Yao W-K, Zheng Y, Liu Y, Duan X-M Wang Y-P (2017). Identification of prognostic factors in patients with diffuse large B-cell lymphoma. Indian Journal of Pathology and Microbiology, 60 (1): 87-91.

Shehata AMF, Aldesoky AI Gohar SF (2019). Plasma fibrinogen level as possible prognostic biomarker in diffuse large Bcell lymphoma. Hematology, 24 (1): 103-107.
Shustik J, Han G, Farinha P, Johnson NA, Ben Neriah S, Connors JM, et al. (2010). Correlations between BCL6 rearrangement and outcome in patients with diffuse large B-cell lymphoma treated with CHOP or R-CHOP. Haematologica, 95 (1): 96101.

Swerdlow Sh CE, Harris NI, Jaffe Es, Pileri Sa, Stein $H$, Thiele J 2017. WHO Classification of Tumours of Haematopoietic and Lymphoid Tissues,4th Ed., World Health Organizaition.

Teras LR, Desantis CE, Cerhan JR, Morton LM, Jemal A Flowers CR (2016). 2016 US lymphoid malignancy statistics by World Health Organization subtypes. CA Cancer J Clin, 66 (6): 443459.

Uherova P, Ross CW, Schnitzer B, Singleton TP Finn WG (2001). The clinical significance of CD10 antigen expression in diffuse large Bcell lymphoma. Am J Clin Pathol, 115 (4): 582-8.

Van Imhoff GW, Boerma E-JG, Van Der Holt B, Schuuring E, Verdonck LF, KluinNelemans HC Kluin PM (2006). Prognostic Impact of Germinal Center-Associated Proteins and Chromosomal Breakpoints in Poor-Risk Diffuse Large B-Cell Lymphoma. Journal of Clinical Oncology, 24 (25): 4135-4142.

Xu Y, Mckenna RW, Molberg KH Kroft SH (2001). Clinicopathologic analysis of CD10+ and CD10- diffuse large B-cell lymphoma. Identification of a high-risk 
subset with coexpression of CD10 and bcl-2. Am J Clin Pathol, 116 (2): 183-90.

Yan L-X, Liu Y-H, Luo D-L, Zhang F, Cheng Y, Luo X$L$, et al. (2014). MYC expression in concert with BCL2 and BCL6 expression predicts outcome in Chinese patients with diffuse large Bcell lymphoma, not otherwise specified. PloS one, 9 (8): e104068-e104068.

Zhang Z, Shen Y, Shen D Ni X (2012). Immunophenotype classification and therapeutic outcomes of Chinese primary gastrointestinal diffuse large B-cell lymphoma. BMC Gastroenterol, 12: 77-84. 